\title{
Uropathogenic Escherichia coli Toxins Induce Caspase-Independent Apoptosis in Renal Proximal Tubular Cells via ERK Signaling
}

\author{
Ming Chen ${ }^{a}$ Timo J ahnukainen ${ }^{a}$ Wenjie Bao $^{b}$ Elisabetta Daréc \\ Sandra Ceccatellic Gianni Celsia \\ aPediatric Nephrology Unit, bepartment of Microbiology, Pathology and Immunology, Division of Pathology, and \\ cThe National Institute of Environmental Medicine, Division of Toxicology and Neurotoxicology, \\ Karolinska Institutet, Stockholm, Sweden
}

\author{
Key Words \\ Pyelonephritis - Renal scar - Escherichia coli toxins · \\ Caspases · ERK · LPA
}

\begin{abstract}
Background: Pyelonephritis is a risk factor for renal tubular epithelial cell damage. Recent studies have shown that Escherichia coli and/or its toxins may stimulate apoptotic cell death in renal tubular cells, but the underlying molecular mechanisms remain to be elucidated. Methods: Confluent LLC-PK 1 cells were exposed to E. coli toxins from overnight cultures of the uropathogenic O6K13H1 (O6) and the nonpathogenic W3110. The cell death was studied with morphological and biological assay. Results: E. coli soluble toxins from uropathogenic 06:K13:H1(06) strain were found to induce apoptosis in a dose- and time-dependent manner in LLC-PK1 cells. The expression of FasR and the phosphorylation of ERK1/2 were significantly upregulated by $\mathrm{O} 6$ soluble toxins in a time-dependent manner. Cell death was completely inhibited by two specific ERK1/2 inhibitors, but not by a broad caspase inhibitor, zVAD-fmk, implicating a caspase-independent pathway via ERK. Moreover, we found that lysophosphatidic acid could trigger a survival signal through G-proteins and PI3K. Conclusion: We demonstrate that apoptosis induced by uropathogenic
\end{abstract}

E. coli toxins is dependent on ERK1/2. Caspases, although being activated, are not necessary for cell death, and they act after the ERK signaling at which point cells become committed to cell death or can be rescued.

Copyright $\odot 2003$ S. Karger AG, Basel

\section{Introduction}

Pyelonephritis is one of the most common febrile bacterial diseases in children. If not treated appropriately, it may cause irreversible renal scar leading to renal failure. Epidemiological studies demonstrate that Escherichia coli is the primary causative organism for urinary tract infections. Virulence factors, such as fimbriae and pili, facilitate bacteria adhesion to the uroepithelial cells [1, 2]. In mice, E. coli-infected bladder cells undergo apoptosis to eliminate invading bacteria [3], and pyelonephritogenic $E$. coli adhesion results in cytotoxicity in cultured renal cells [4]. Moreover, enterohemorrhagic E. coli-derived Shiga-like toxins can also induce apoptosis in proximal tubular cells [5]. However, the molecular mechanism by which $E$. coli toxins cause renal damage remains under active investigation. A previous study has shown that uropathogenic E. coli $\mathrm{O} 6 \mathrm{~K} 13 \mathrm{H} 1$ (O6) produce toxins that generate intracellular $\mathrm{Ca}^{2+}$ oscillations in renal tubular cells and promote gene transcription [6]. This present

\begin{tabular}{ll}
\hline KARGER & ( 2003 S. Karger AG, Basel \\
0250-8095/03/0233-0140\$19.50/0 \\
$\begin{array}{l}\text { Fax +41613061234 } \\
\begin{array}{l}\text { E-Mail karger@karger.ch } \\
\text { www.karger.com }\end{array}\end{array}$ & $\begin{array}{l}\text { Accessible online at: } \\
\text { www.karger.com/ajn }\end{array}$
\end{tabular}

Ming Chen
Department of Pediatrics, B62
Huddinge University Hospital
SE-141 86, Stockholm (Sweden)
Tel. +46 88581673 , Fax +46 858587370 , E-Mail Ming.Chen@klinvet.ki.se 
study was therefore designed to further characterize the effects of E. coli $\mathrm{O} 6$ on proximal tubular epithelial cells.

Apoptosis, which is an active energy-requiring cell death, plays a critical role in renal tubular damage after exposure to various stimuli and it is involved in a variety of biological processes and during response to bacteria invasion $[7,8]$. Caspases are important mediators of the regulation and execution of apoptotic cell death. The activation of caspase 3 has been correlated with renal apoptosis and development of scarring in the experimental remnant kidney model [9]. However, apoptosis can also proceed in a caspase-independent manner $[10,11]$. The Fas receptor (FasR) activates mitogen-activated protein kinase (MAPK), ERK1/2, which is involved in caspasedependent and -independent apoptosis and may function as an upstream signaling for caspase activation [12-15].

Counteracting death signals, survival factors have been likened to efficiently inhibit a default apoptotic pathway that is ready to be executed [16-18]. Lysophosphatidic acid (LPA) is a natural lysophospholipid with high affinity to serum albumin. Recently, LPA has also been found to be as a survival factor and to inhibit cell death via Gproteins and/or PI3K $[18,19]$. In the present paper we also investigated the potential role of LPA as anti-apoptotic factor in E. coli pyelonephritis.

\section{Materials and Methods}

\section{Reagents}

Unless indicated otherwise, all chemicals were purchased from Sigma (St. Louis, Mo., USA). Cell culture medium and plastic ware were from Life Technologies (Gaithersburg, Md., USA). Albumin was from Dade Behring. Lysophosphatidic acid was from VANTI POLAR-LIPIDS, Inc., Alabaster. Benzyloxycarbonyl-Val-Ala-Aspfluoromethyl ketone (zVAD-fmk), Ac-Asp-Glu-Val-Asp- $\alpha$-(4-methyl-coumaryl-7-amide) (DEVD-MCA) was from Peptide Institute (Minoh-Shi, Osaka). MTT Assay Kit was from Promega (Madison, Wisc., USA).

\section{Preparation of Bacteria Soluble Toxins}

The human and rat pyelonephritogenic E. coli strain ARD6 (serotype O6: K13: H1) [20] was grown on LB-agar plates, then one colony of bacteria was cultured overnight in $10 \mathrm{ml}$ Luria-Bertani (LB) medium at $37^{\circ} \mathrm{C}$ until optical density reached 1.2 . This culture was centrifuged, the supernatant was collected and bacteria pellet was discarded. The remaining supernatant (soluble toxins) was sterilized by $0.22 \mu \mathrm{m}$ filtration. The nonpathogenic $E$. coli strain W3110 [21] was compared.

Cell Culture and Treatment

LLC-PK1 cell line from porcine proximal tubule (European Collection of Animal Cell Cultures, ECACC) was maintained in medium-199 (M199) containing penicillin (50 U/ml) and streptomycin $(50 \mu \mathrm{g} / \mathrm{ml})$ and supplemented with $10 \%$ fetal calf serum (FCS). Cells were grown to confluence (untreated), then kept in $0.2 \%$ FCS medium for $4 \mathrm{~h}$. Soluble toxins from uropathogenic $E$. coli $\mathrm{O} 6 \mathrm{~K} 13 \mathrm{H} 1$ (O6 group) or nonpathogenic W3110 strain (W3110 group) were added at a final dose of $100 \mu \mathrm{l} / \mathrm{ml}$. Cells left in $0.2 \%$ FCS medium were the control group (control, con). Cells were then collected for different assays by scraping or trypsinization. Albumin $(1 \mathrm{mg} / \mathrm{ml})$, lipid-free albumin $(1 \mathrm{mg} / \mathrm{ml})$ and LPA $(30 \mu M)$ were added to the cell culture just before adding the bacteria soluble toxins. Pertussis toxin (PTX, $200 \mathrm{ng} / \mathrm{ml}$ ) was added $6 \mathrm{~h}$ before other substances. Wortmannin (Wort, $200 \mathrm{n} M$ ), PD98059 (PD, $50 \mu M$ ), U0126 (U0, $20 \mu M$ ) and cycloheximide $(4 \mu M)$ were added $30 \mathrm{~min}$ before bacterial soluble toxins. zVAD-fmk $(35 \mu M)$ was added to the cell culture $20 \mathrm{~h}$ after the bacterial soluble toxins. We performed dose-dependent curves for all the above chemicals and the results were all in agreement with the literature.

\section{Cell Viability}

Trypan blue (T.B) Exclusion Test. As previously described [22], cells with damaged cell membranes were stained blue (necrotic cells), while cells with intact plasma membranes remained unstained (apoptotic and healthy cells).

MTT Assay. MTT assay was based on the ability of mitochondria from viable cells to cleave the tetrazolium rings of the pale yellow MTT (3-(4,5-dimethylthiazol)-2,5-diphenyl tetrazolium bromide) resulting in formation of a dark blue formazan product. After removal of medium from 24-well plates, the cells were incubated with MTT. The MTT formazan precipitate was dissolved and read under a microplate reader (Dynatech, Chantilly, Va., USA) with a test wavelength of $562 \mathrm{~nm}$ and a reference wavelength of $660 \mathrm{~nm}$. The experiments were run at least three times in triplicates.

Caspase 3-Like Activity. We use DEVD-MCA as a fluorogenic substrate to evaluate the caspase 3-like activity, as previously described [22]. Briefly, cells were removed by gentle scraping. Substrate cleavage leading to release of free MCA (excitation $355 \mathrm{~nm}$, emission $460 \mathrm{~nm}$ ) was monitored at $37^{\circ} \mathrm{C}$ using Fluoroskan II (Labsystem AB, Stockholm). Caspase 3-like activity was expressed in $\mathrm{pmol} / \mathrm{min} / \mu \mathrm{g}$ protein.

\section{Western Blotting}

Cells were lysed in urea sample buffer $(62.5 \mathrm{~m} M$ Tris- $\mathrm{HCl}, \mathrm{pH}$ 6.8; $6 \mathrm{M}$ urea; $10 \%$ glycerol; $2 \% \mathrm{SDS} ; 0.00125 \%$ bromophenol blue; $5 \% \beta$-mercaptoethanol), sonicated for $15 \mathrm{~s}$ and then incubated at $65^{\circ} \mathrm{C}$ for $15 \mathrm{~min}$. Proteins were detected as previously described [23]. PARP was detected with anti-PARP antibody (Santa Cruz, Calif., USA). ERK1/2 activity and total ERK were determined with antiphospho-ERK1/2 and anti-total ERK antibody (BioLab, New England, London). Fas Receptor (FasR) was examined by anti-fas antibody (Santa Cruz, Calif., USA).

\section{DNA Ladder}

Internucleosomal DNA fragments were detected primarily by DNA laddering. Briefly, cells from 6-well plates were pelleted and lysed in $500 \mu \mathrm{l}$ of lysis buffer ( $5 \mathrm{~m} M$ Tris-HCL, pH 8.0, $20 \mathrm{~m} M$ EDTA and $0.5 \%$ triton X-100), then centrifuged at $15,000 \mathrm{rpm}$ for $15 \mathrm{~min}$. The supernatant was precipitated with ethanol and $5 \mathrm{M} \mathrm{NaCl}$ overnight at $-20^{\circ} \mathrm{C}$. The samples were centrifuged at $15,000 \mathrm{rpm}$ for 15 min again and supernatant was discarded. The chromosomal DNA was extracted with RNAase and protease $\mathrm{K}(1 \mathrm{mg} / \mathrm{ml})$ for $1 \mathrm{~h}$ at $37^{\circ} \mathrm{C}$, respectively. The DNA samples were separated by $1.8 \%$ agarose gel electrophoresis followed by staining with ethidium bromide. 
Annexin-V/Propidium Iodide (PI) Staining

Early apoptotic cells were identified by annexin V-fluorescein isothiocyanate (FITC) detection kit (Annexin Alexa, Molecular Probe) Cells on cover slips were washed in annexin-binding buffer; then $3 \mu \mathrm{l} / 100 \mu \mathrm{l}$ of annexin V-FITC and $0.1 \mu \mathrm{g} / 100 \mu \mathrm{l}$ of PI were added for $15 \mathrm{~min}$ in the dark at room temperature. The cells were examined under fluorescent microscopy (Nikon, Japan). Apoptotic cells were stained green and necrotic cell nuclei were stained red.

\section{Immunocytochemistry}

The cells were grown on coverslips, washed with PBS, fixed with $3.7 \%$ formaldehyde in PBS for $15 \mathrm{~min}$ at $4{ }^{\circ} \mathrm{C}$ and washed with $0.1 \%$ Tween-20 in PBS. Then the cells were incubated with a mouse monoclonal antibody (1:100 dilution in 1\% BSA and 0.1\% Tween-20 in PBS) against cleaved CK 18 (CK18 clone M30, Boehringer Mannheim) overnight at $4^{\circ} \mathrm{C}$. After washing with PBS, the cells were incubated with a secondary anti-mouse-fluorescein antibody (1:500 dilution in $1 \% \mathrm{BSA}$ and $0.1 \%$ Tween-20 in PBS) at room temperature for $2 \mathrm{~h}$. The coverslips were mounted on slides with anti-fade mounting solution and examined under fluorescent microscope.

\section{Statistical Analysis}

Values are mean \pm SEM, $n=3-5$ in each group. Cell viability is presented as percentage of untreated cells. Statistical analysis was performed using ANOVA followed by Tukey-Kramer multiple comparison test.

\section{Results}

\section{Uropathogenic E. coli Strain (O6) Soluble Toxins}

Induced Cell Death

To determine the cytotoxicity of O6-soluble toxins in LLCPK 1 cells, we incubated the cells with $100 \mu \mathrm{l} / \mathrm{ml}$ of O6 toxins for $24-72 \mathrm{~h}$. More than $40 \%$ cells died $44 \mathrm{~h}$ after incubation, while no significant cell death was observed before $44 \mathrm{~h}$ (fig. 1a). After $72 \mathrm{~h}$ incubation or high dose (over $200 \mu \mathrm{l} / \mathrm{ml}$ ) of O6 toxins, we observed more necrotic or detached cells, while low dose of O6 toxins $(50 \mu \mathrm{l} / \mathrm{ml})$ caused no cell death (data not shown). MTT assay supported that there were less viable cells in $\mathrm{O} 6$ group at $44 \mathrm{~h}$ (fig. 1b). Meanwhile, we observed cell shrinkage, membrane blebbing and the appearance of brightly rounded bodies under phase contrast microscopy (fig. 1c, right panel), implying the occurrence of apoptosis. On the contrary, incubation with nonpathogenic $E$. coli W3110 affected neither cell viability nor morphology at any time after incubation (fig. 1,2). Furthermore, O6induced cell death was not significantly changed after coincubation with $100 \mu 1 / \mathrm{ml}$ of $\mathrm{W} 3110$, as determined under phase contrast microscopy and by trypan blue exclusion test (data not shown), indicating that O6 toxins were toxic and that there was no competition between the two strains.
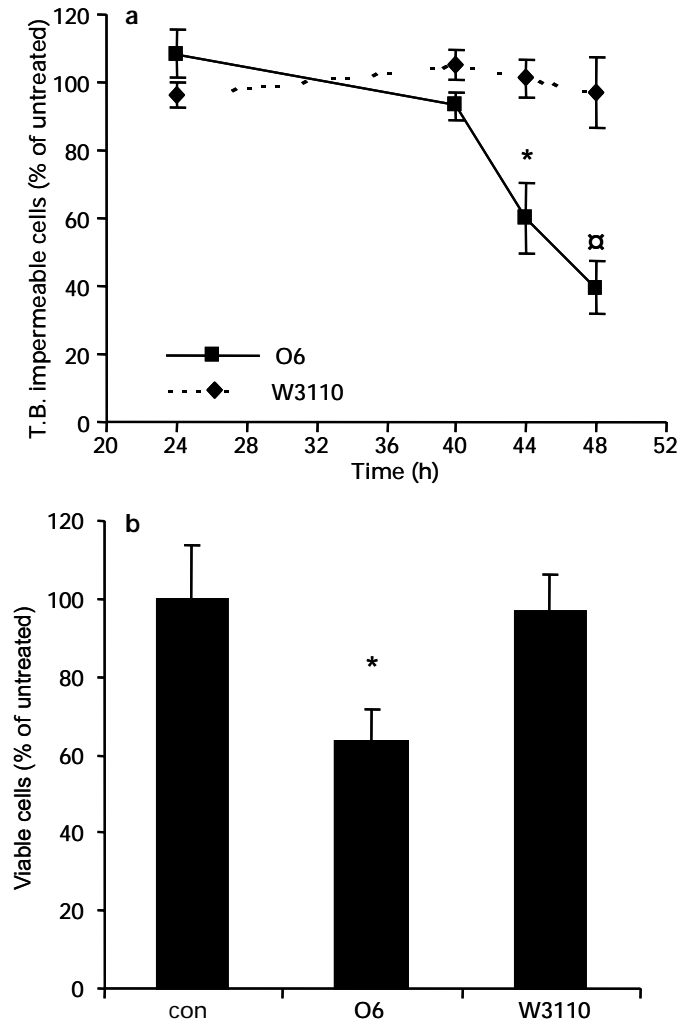

c
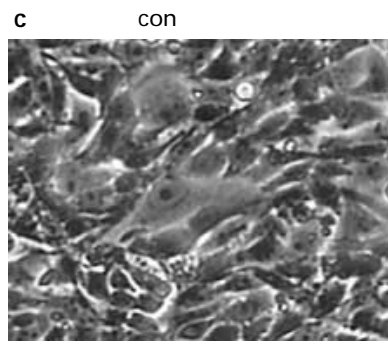

06

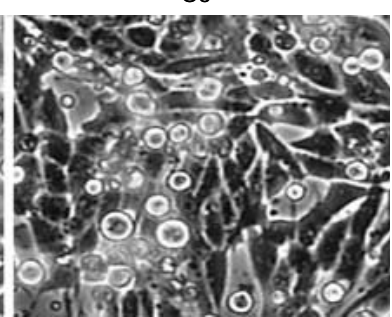

Fig. 1. Cell viability after exposure to O6 or W3110. LLCPK1 cells were exposed to $\mathrm{O} 6$ or W3110 for indicated time. Cell viability was examined by trypan-blue (TB) exclusion test (a) and MTT assay (b). Cells become shrunken, rounded and membrane blebbing was demonstrated with phase contrast microscopy (c). Values are means \pm SEM, $\mathrm{n}=3-4 .{ }^{*} \mathrm{p}<0.001,{ }^{\circ} \mathrm{p}<0.0001$ as compared to control and W3110.

Fig. 2. PS exposure after cells incubated with O6. In O6-group rounded apoptotic bodies (up middle panel) were stained by annexin-V-FITC (green) (bottom middle panels) and few cells were also stained by PI (red) in the nucleus. No annexin-V staining was observed in con. and W3110 groups. Shown are representatives of five independent experiments. 

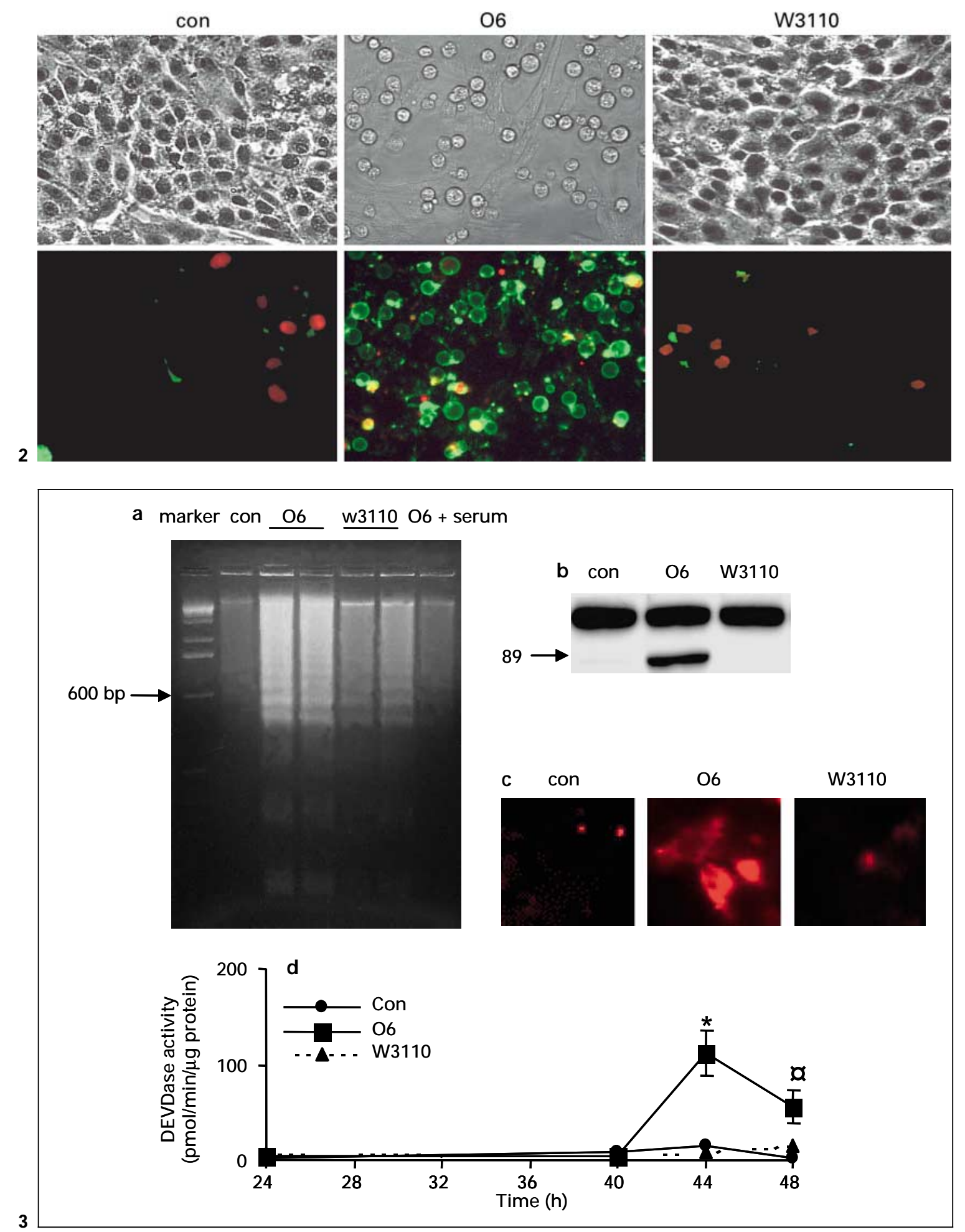

Fig. 3. Induction of DNA degradation, PARP and CK 18 cleavage and caspase 3 -like activity by $\mathrm{O} 6$ toxins. Cells were incubated with O6-toxins, W3110 supernatant or O6-toxins together with $10 \%$ serum. Cells were harvested for determining DNA ladder in agarose gel, PARP cleavage with western, CK 18 cleavage with immunocytochemical staining and caspase 3-like protease activity as cleavage of
DEVDase (see 'Methods'). The typical DNA ladder of apoptosis (a), cleavage of PARP (b), CK 18 cleavage on cell membranes (c) and caspase 3-like protease activity (d) were only found in O6-group. Images are representatives of 3-6 independent experiments. Values are mean \pm SEM of five experiments, ${ }^{*} \mathrm{p}<0.001,{ }^{\circ} \mathrm{p}<0.01 \mathrm{com}-$ pared to $24 \mathrm{~h}$. 


\section{O6-Induced Cell Death Displayed Apoptotic Features}

To confirm that O6-induced cell death is apoptotic in nature, we further assayed cells with biochemical markers of apoptosis. Annexin V staining appeared at $40 \mathrm{~h}$ (data not shown) after O6 incubation and was very evident at $44 \mathrm{~h}$ in the shrunken, blebbed and rounded cells (fig. 2, bottom middle panel), but not occurring in control or after W3110 incubation (fig. 2, bottom left and right). At same time point, few cells were also positive for PI, implying necrotic death (fig. 2, bottom middle panel). More PIpositive cells appeared with prolonged incubation time (data not shown), indicating that secondary necrosis occurred in later stages. To further confirm the O6-induced cell death is an active process, we utilized a protein synthesis inhibitor, cycloheximide, to block the programmed cell death cascade. As expected, cycloheximide $(4 \mu M)$ inhibited O6-induced death as studied by morphology (data not shown) and viability test (O6: $52 \pm 8.7 \%$ vs. O6 + CHX: $93 \pm 10.3 \%, \mathrm{n}=3$ ).

As shown in figure $3 \mathrm{a}$, a stronger DNA laddering pattern consistent with inter-nucleosomal DNA cleavage was observed after $44 \mathrm{~h}$ incubation with O6-soluble toxins but not in the control or W3110 group. Furthermore, cleavage of caspase substrate PARP, a hallmark of apoptosis was evident (fig. 3b). In the cells co-incubated with O6 and W3110, DNA ladder and PARP cleavage were still observed (data not shown). Using immunocytochemical assay (fig. 3c), we demonstrated the specific cleavage of the caspase substrate CK 18 on apoptotic cell membranes. No such staining was observed in control and W3110 groups. All evidence supported that O6-toxins mediated apoptotic phenomenon.

\section{O6-Induced Cell Death Was Independent of Caspase} Activation

Since O6-toxins induced caspase-dependent cleavage of several substrates, caspase 3-like activity was measured (fig. 3d). A significant increase (over 100-fold) in caspase 3-like protease activity was found after cells exposure to O6-toxins for $44 \mathrm{~h}$. No increase in caspase 3-like protease activity was detected in the control and W3110 groups. It is known that cell death occurs via both caspase-dependent and -independent pathways [24, 25]. Therefore, we used a pan-caspase inhibitor zVAD-fmk to investigate whether caspase activation is necessary for O6-dependent cell death. Cells were exposed to zVAD-fmk $(35 \mu M) 20 \mathrm{~h}$ after addition of $\mathrm{O} 6$ toxins since in pilot experiments we found that longer exposure time $(44 \mathrm{~h})$ to $\mathrm{zVAD}$-fmk alone resulted in cytotoxicity. Addition of the caspase inhibitor completely abolished the O6-induced caspase 3like activation (fig. 4b). However, zVAD-fmk could not

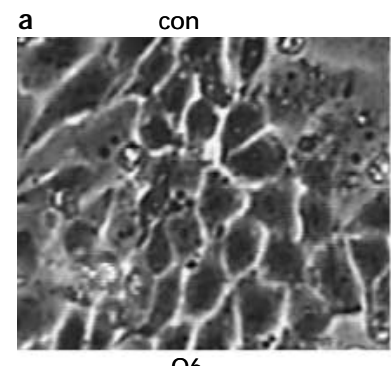

06
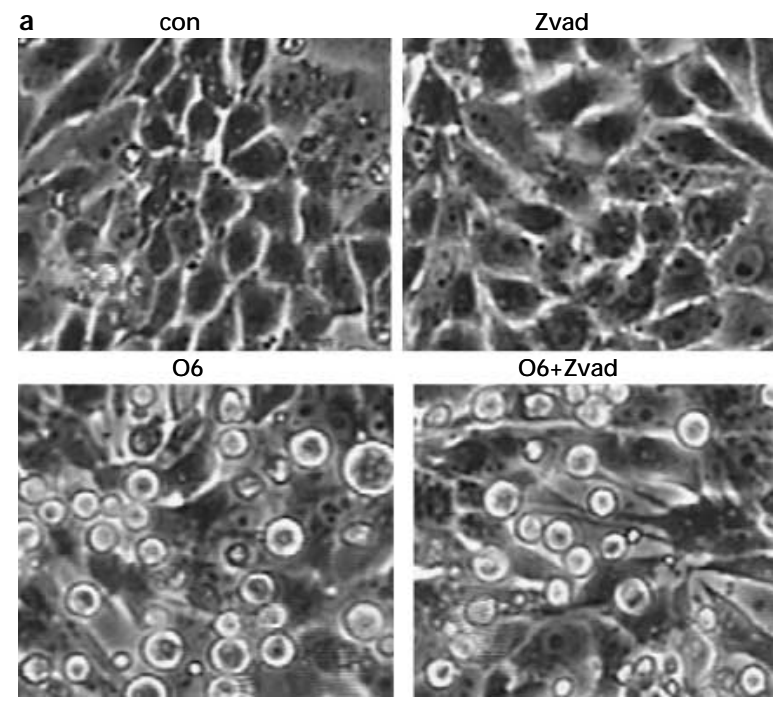

O6+Zvad
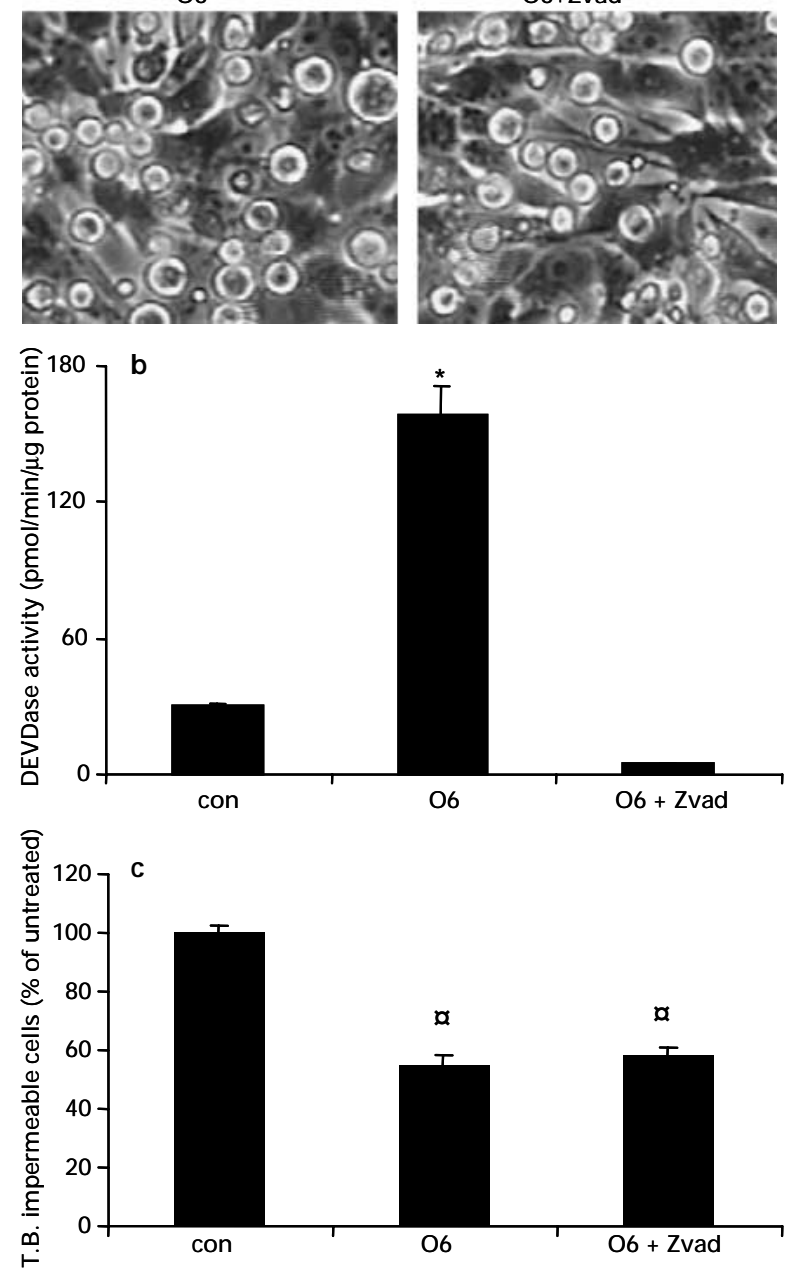

Fig. 4. $z V A D$-fmk blocked caspase 3-like activity but not cell death. Cells were incubated with $\mathrm{O} 6$ for $44 \mathrm{~h}$, zVAD-fmk $(35 \mu M)$ was added during the last $24 \mathrm{~h}$. a Phase-contrast microscopy. b Caspase 3like activity detected with fluorogenic DEVDase cleavage assay. c Cell viability was determined by trypan blue exclusion test. Image is representative of three independent experiments. Values are mean \pm SEM, $\mathrm{n}=3-5 .{ }^{*} \mathrm{p}<0.001$ compared to O6 + zVAD; ${ }^{a} \mathrm{p}<0.05$ compared to con. 
Fig. 5. MEK $1 / 2$ inhibitors blocked O6-induced activation of ERK, cell death and caspase 3-like activity. Cells were incubated with $\mathrm{O} 6$ in the presence or absence of PD98059 $(50 \mu M)$ and U0126 $(20 \mu M)$ for $44 \mathrm{~h}$. a Phosphorylated ERK and total ERK were detected with anti-phospho-ERK and total-ERK antibody by immunoblotting. b Phase contrast microscopy. c Cell viability. d Caspase 3-like activity. Image is representative of three independent experiments. Values are mean \pm SEM, $\mathrm{n}=4-5 .{ }^{a} \mathrm{p}<$ 0.001 compared to con; $* \mathrm{p}<0.01$ compared to O6.

Uropathogenic E. coli Toxins Induce Apoptosis via ERK a

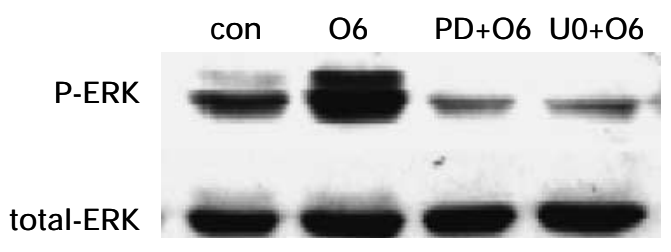

b

PD

U0

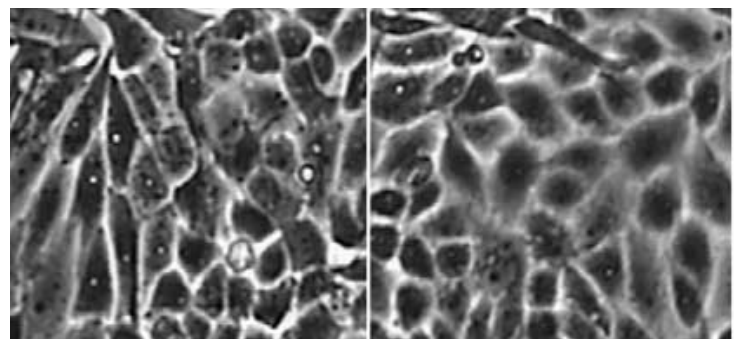

06

$\mathrm{PD}+06$

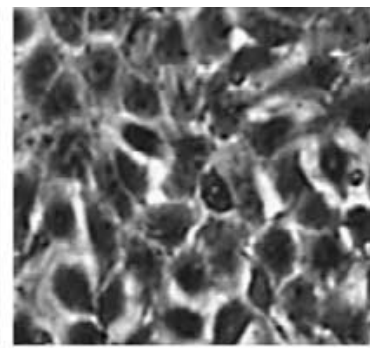

$\mathrm{U} 0+06$
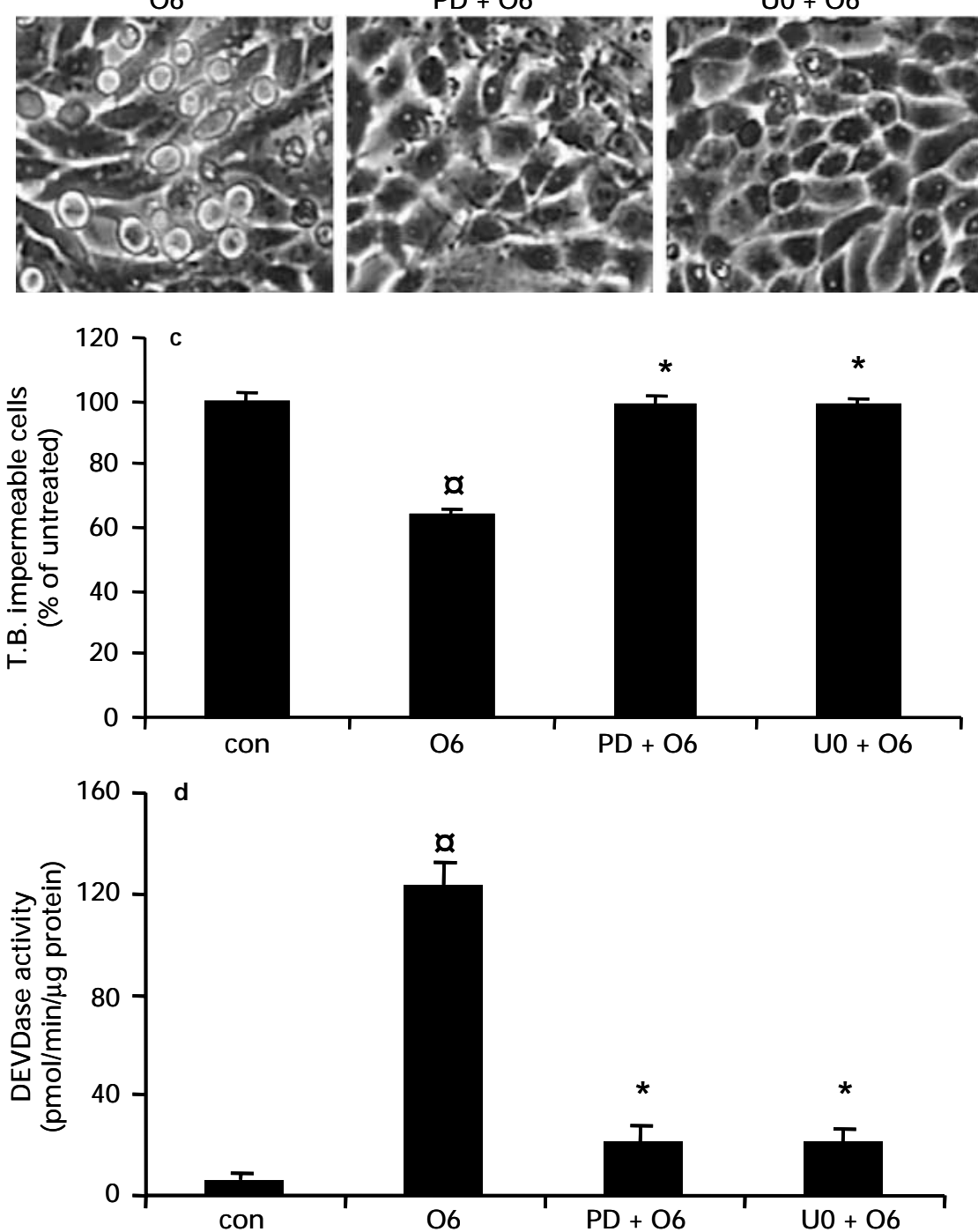


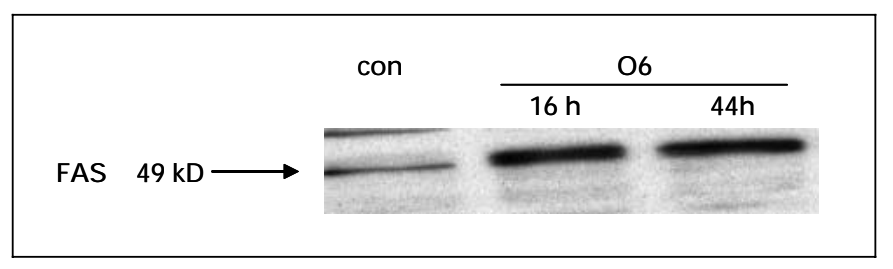

Fig. 6. Up-regulation of FasR expression. Cells were incubated with O6 toxins. Western blot shows that expression of FasR was upregulated after 16 and $44 \mathrm{~h}$. Shown are representatives of 5 experiments.

reduce cell death, as judged by morphology of the cells (fig. 4a) and by trypan blue viability test (fig. 4c), suggesting that cell death is independent of caspase activation.

\section{O6-Induced Cell Death Required ERK1/2}

MAPK ERK1/2 and p38 have been shown to be upstream signaling molecules in the apoptotic pathway in several cell types [12, 13, 33]. We found that phosphorylated ERK1/2 was significantly increased (no change of total ERK) after O6 incubation, in parallel with the occurrence of cell death and the increase in caspase 3-like activity (fig. 5). Two inhibitors of MEK $1 / 2$ (the direct activator of ERK), PD98059 (50 $\mu M)$ and U0126 $(20 \mu M)$, completely blocked ERK1/2 phosphorylation (fig. 5a) and prevented cell death by nearly $100 \%$ (fig. 5b, c) as well as the increase in caspase 3-like activity (fig. 5d). A specific inhibitor of p38 MAPK, SB203580 $(10 \mu M)$, did not block O6-induced cell death, as determined by morphological changes and caspase assay (con: $19 \pm 2.8 \mathrm{pmol} /$ $\mathrm{min} / \mu \mathrm{g}$ protein; O6: $181 \pm 24 ; \mathrm{O} 6+\mathrm{SB}: 135 \pm 30 ; \mathrm{n}=3$ ). At higher concentrations, SB203580 was toxic to the cells. These results suggested that ERK1/2 phosphorylation appears to be a crucial signal for cell death and it might be upstream of caspases activation.

\section{Fas Was Upregulated in O6-Induced Cell Death}

The FasR activates all major signaling pathways that belong to the family of MAPK, by either caspase-independent or -dependent mechanisms [14, 15]. Therefore, we examined the expression of FasR after exposure to O6toxins. We found that FasR was upregulated from 16 up to $44 \mathrm{~h}$ after incubation with O6-toxins (fig. 6). Consistent with activation of Fas-pathway, caspase 8 mRNA expression was upregulated at $44 \mathrm{~h}$ as shown by RT-PCR, while no change of Bax mRNA expression, a hallmark of caspase 9-cascade was observed [unpubl. obs.]. These data suggested that the Fas-caspase 8 pathway might be stimulated in O6-mediated apoptotic cell death.
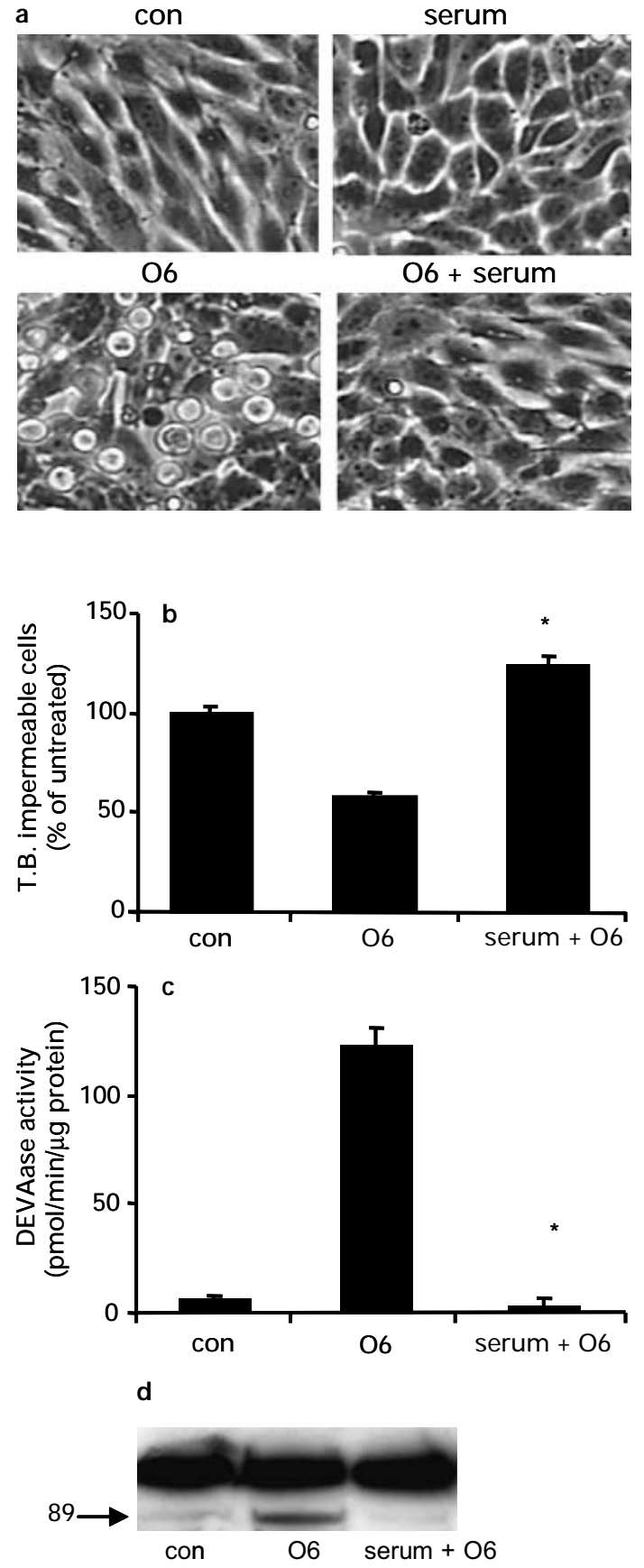

Fig. 7. Protective effect of serum factors on O6-induced cell death. Cells were incubated with O6 toxins. a Phase-contrast microscopy. b Cell viability. c Caspase 3-like activity. d PARP cleavage. Results are from 3-4 independent experiments, respectively. Values are mean \pm SEM. $*$ p $<0.05$ compared to O6. 
Fig. 8. Effects of albumin-bound lipid(s) on O6-induced cell death. Cells were incubated with $\mathrm{O} 6$ in presence of $1 \mathrm{mg} / \mathrm{ml}$ serum albumin $(\mathrm{AL}+\mathrm{O} 6)$ or lipid-free albumin $(\mathrm{LF}+\mathrm{O} 6)$ for $44 \mathrm{~h}$. Cells were observed under phase contrast microscopy (a), and harvested for viability (b), caspase 3-like activity (c) and PARP cleavage (d). Results are from three independent experiments. Values are mean \pm SEM. $* \mathrm{p}<0.001$ compared to O6; ${ }^{a} \mathrm{p}<0.05$ compared to LF + O6.
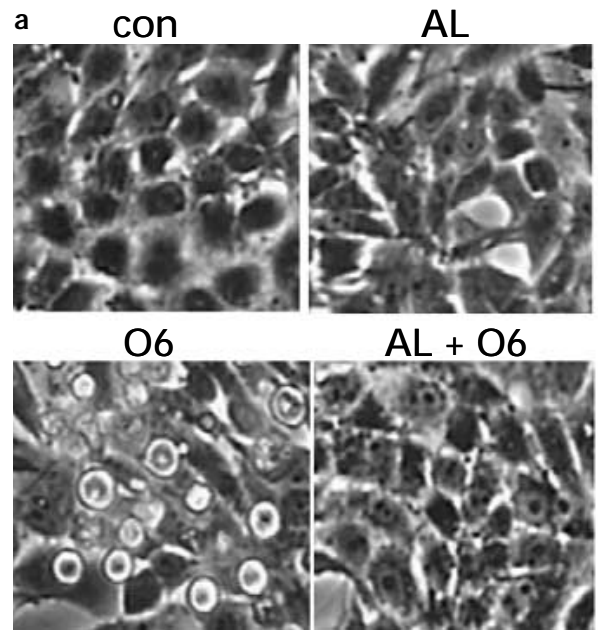

$A L$
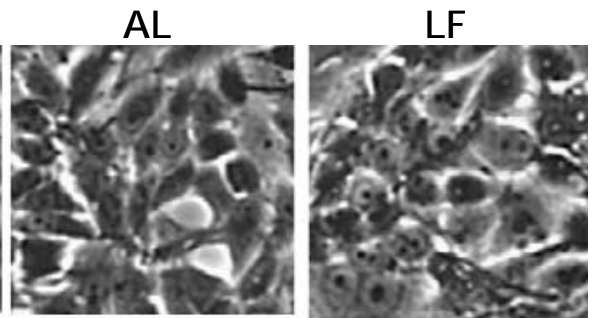

$\mathrm{LF}+\mathrm{O} 6$
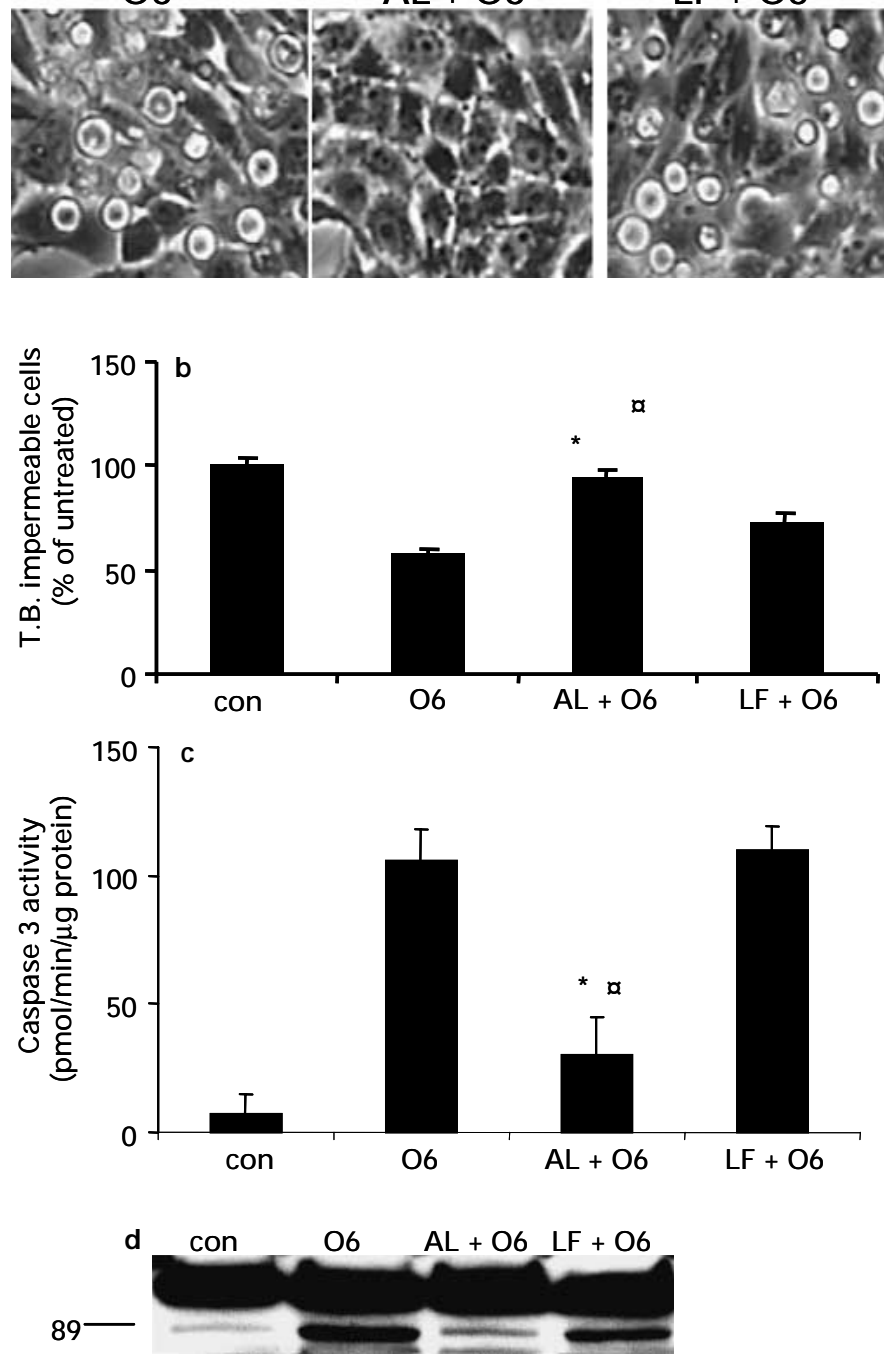

\section{Serum Factors Prevented Cell Death}

To identify survival factors, cells were incubated with O6 in the presence of $10 \%$ serum, no cell death was observed (fig. 7a, b) and caspase activation (fig. 7c), PARP cleavage (fig. 7d) and DNA fragmentation (fig. 3a) were abolished. It has been shown that serum albumin and albumin-bound lipids may inhibit apoptosis [26, 27]. Therefore, we tested albumin (not lipid-free, AL) and lipid-free albumin (LF) to prevent O6-dependent cell death. Addition of $1 \mathrm{mg} / \mathrm{ml}$ of AL inhibited cell death, caspase activation and PARP cleavage, while the same concentration of LF did not prevent cell death (fig. 8). It has been 
Fig. 9. Effects of LPA on cell survival. Cells were incubated with $\mathrm{O} 6$ and $30 \mu M$ LPA $(\mathrm{LP}+\mathrm{O} 6)$ in the presence or absence of $200 \mathrm{n} M$ Wortmannin (Wort + LPA + O6) or $200 \mathrm{ng} / \mathrm{ml}$ pertussis toxin $(\mathrm{PTX}+\mathrm{LPA}+\mathrm{O} 6)$ for $44 \mathrm{~h}$. Cells were observed under phase contrast microscopy (a), and harvested for viability (b) and caspase 3-like activity (c). Values are mean \pm SEM of three experiments. ${ }^{*} \mathrm{p}<0.05$ compared with LPA + O6.

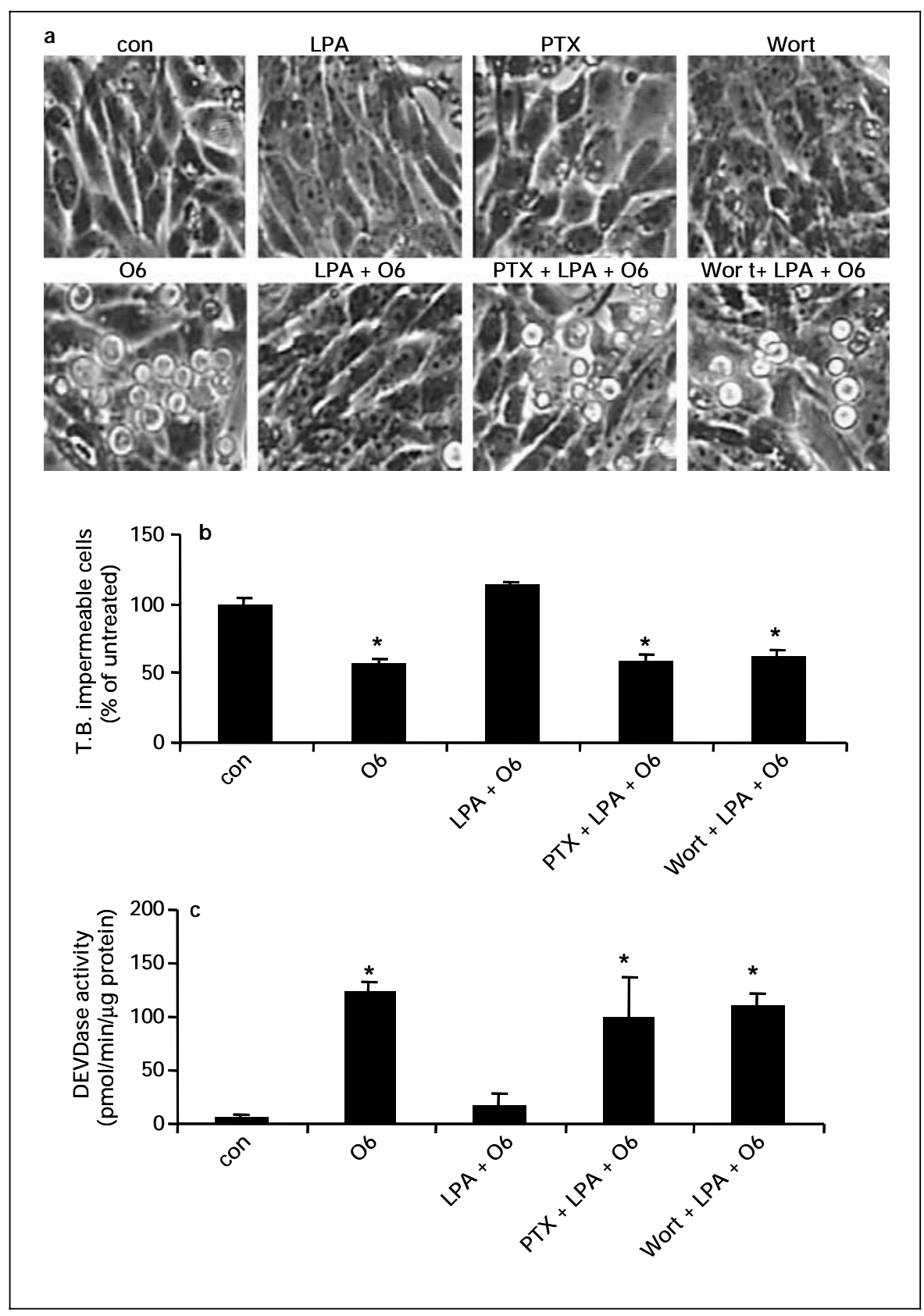

suggested that LPA is an albumin-bound lipid with antiapoptotic effect $[26,27]$. We found that LPA $(30 \mu M)$ abolished O6-dependent cell death and caspase 3-like activity (fig. 9). The inhibitory effect of LPA on apoptosis was abrogated when cells were pretreated with pertussis toxin or Wortmannin (fig. 9), consistent with LPA acting via a G-protein and PI3K-dependent pathway $[18,28]$.

\section{Discussion}

The present study demonstrates that uropathogenic E. coli $\mathrm{O} 6 \mathrm{~K} 13 \mathrm{H} 1$ produces soluble toxins that induce cell death in renal proximal tubular epithelial cells. The morphological and biochemical alterations induced by E. coli toxins were compatible with apoptosis. Cell death appears to be an ERK-mediated phenomenon. Caspases, although activated during the apoptotic process, do not seem to be 
crucial for cell death. Furthermore, we show that serum contains one or more factors, such as LPA, that may prevent apoptosis.

The $E$. coli family consists of a heterogeneous group of strains whose virulence factors against epithelial cells remain largely unknown, except for their adhesion properties [20] mediated by interaction between host-cell receptors and bacterial proteins [29, 30]. Soluble $E$. coli toxins, such as Shiga toxin-like and verotoxin, have been shown to contribute to epithelial cell death in hemolytic uremic syndrome (HUS) in vivo and in vitro [5, 20]. Hemolysin is the prototype of another large protein family of pore-forming toxins produced by gram-negative organisms. It kills a wide range of cell types including renal tubular epithelial cells. Pyelonephritogenic E. coli, which produce hemolysin, induce high cytotoxicity in renal tubular epithelium [4]. In addition, E. coli hemolysin directly activates intracellular $\mathrm{Ca}^{+}$oscillations in absence of bacterial adhesion [6]. The present study extends this observation by showing apoptotic cell death in renal tubular epithelial cells exposed to soluble toxins from E. coli $\mathrm{O} 6 \mathrm{~K} 13 \mathrm{H} 1$, which expresses neither Shiga toxin nor verotoxin. The finding that co-incubation with O6toxins and W3110 supernatant also resulted in apoptosis indicates that $\mathrm{O} 6$ strain is indeed toxic and that the W3110 is not just protective.

The nature of the pro-apoptotic toxins need to be further defined. We found that heating O6-toxins did not abolish cell death [pers. obs.], therefore it is unlikely that apoptosis is directly mediated by the highly thermo-labile hemolysin. Using liquid chromatography analysis, we have isolated several toxins, which seem to act synergistically in activating the apoptotic machinery [Gustaffason L, unpubl. obs.]. When O6 toxins were removed after upregulation of FasR ( $22 \mathrm{~h})$ and the cells were incubated with normal culture medium up to $44 \mathrm{~h}$, no morphological changes nor cell death were observed [unpubl. observation], supporting that FasR must be activated by additional toxins in the next $22 \mathrm{~h}$ to trigger apoptotic event.

Members of the MAPK family have been shown to be involved in the signaling downstream of the FasR $[14,15$, 31]. MAPK ERK1/2 is known to induce cell growth, differentiation and cell death. Several studies support the view that activation of ERK delivers a survival signal to counteract pro-apoptotic effects [32, 33]. Conversely, ERK may also mediate apoptosis [12, 13, 34]. In the present study, we provided evidence that ERK was critical for $E$. coli-induced apoptosis in renal tubule epithelial cells. Utilizing specific ERK inhibitors, we found that both cell death and caspase 3-like activity was completely abolished, consistent with ERK being upstream of caspases in the cell death pathway $[12,13]$. However, using the p38 inhibitor (SB 20580), we were unable to block cell death and caspase activation, indicating that $\mathrm{p} 38$ was not required for cell death in our model. Moreover, it has been recently shown that PD98058 can inhibit both MEK1 and MKK5 in a dose dependent manner in certain cell types [35]. The dose used in this study was mainly compatible with inhibition of MEK1 [36], but we cannot completely rule out the possibility that MKK5 was also involved.

The caspase 3 subfamily (caspase 2, 3 and 7) exerts execution functions in apoptosis. Previous studies about the fate of cells exposed to $E$. coli investigated only internucleosomal DNA cleavage [5, 37], which is a relatively late event in the apoptotic process or in necrosis and may be dissociated from early critical steps of apoptosis. In this study, we found that caspase 3-like proteases were not only dramatically activated in cells exposure to O6-toxins, but also initiates its deadly assault on the cell by selectively cleaving a number of 'death substrates'. Although caspases are a pivotal executioner of mammalian apoptosis $[38,39]$, cells lacking caspase can still undergo death [10, $11,40]$. Our results show that a pan caspase inhibitor, zVAD-fmk, effectively blocked the caspase 3-like activity, but it did not prevent cell death (fig. 4), indicating that caspases orchestrated only part of the effects induced by O6-toxins. It seems that caspases act after the ERK step at which point the cells became committed to cell death or can still be rescued by survival factors. We could not exclude the involvement of (an) other protease(s) in E. coli-induced renal tubule epithelial cell death, with specificity similar to that of caspases, like cathepsin D [41]. Damage of mitochondrial is another possibility of leading to caspase-independent apoptosis [42, 43].

It is well known that apoptosis may be inhibited by several serum factors [19]. We show that high concentration of fetal calf serum (10\%) completely protects cells from O6-mediated death, while low serum concentration $(0.2 \%)$, which is still capable of maintaining cell viability, does not protect against cell death. Serum albumin has been suggested as a survival factor. It may protect cells as a scavenger [44] or by directly inhibiting apoptosis [26]. Furthermore, serum albumin often carries lipids. Our data show that a commercial albumin preparation, which is not devoid of lipids, can inhibit apoptosis. Interestingly, the same dose of a lipid-free albumin cannot inhibit the apoptotic cascade. These results strongly suggest that albumin-bound lipid(s) may play a role in preventing cells from undergoing O6-dependent apoptosis and that the protection is not simply due to quenching of the toxin. 
Molecules carried by albumin include phospholipids such as LPA [45], which is a naturally occurring lysophospholipid and is released by activated platelets and injured cell in several pathophysiological conditions, including infection. It has been shown that LPA may act as a major serum noncytokine survival factor for several cell types, including renal proximal tubular epithelial cells [19]. In vitro, it was tested that the effect of LPA on cell survival is concentration dependent with optimum at $30 \mu M[27$, 46]. In the present study we demonstrated that $30 \mu M$ LPA protected against $E$. coli O6-dependent-apoptosis, a concentration close to that in serum $(5-20 \mu M)(47) .10 \%$ fetal calf serum is able to inhibit apoptosis. The LPA concentration in $10 \%$ fetal calf serum should be lower than $30 \mu M$ and, therefore, we cannot rule out the possibility that other serum factors may be also involved in protecting from apoptosis.

LPA acts via G-protein-coupled receptors (GPCRs) and PI3K-dependent pathways [18, 28]. In our model, when specific inhibitors of GPCRs and of PI3K were used in combination with LPA, apoptosis was still detected, indicating a specific effect of LPA via Gi- Ras-Raf-PI3K pathway. Moreover, Wort and PTX could also inhibit the protective effect of AL (the albumin preparation not devoid of lipids) (data not shown), indicating that this effect is also mediated by GPCRs and PI3K. Therefore, these data strongly suggests that the albumin-bound lipid protecting against apoptosis may indeed be LPA. It has been hypothesized that cell proliferation occurs in regions where tubular injury had occurred and that local factors released in response to cellular injury, may mediate nephron repair by acting in an autocrine and/or paracrine fashion [48]. It is likely that LPA plays a role as a local growth factor in response to cell injury, wound healing and inflammation, and may be part of a cascade that is triggered by invading bacteria during urinary tract infection.

In conclusion, this study indicates that during urinary tract infection, renal tubular epithelial cells are exposed to E. coli toxins and may undergo ERK-mediated cell death, but they may be protected from cell death by local survival factors released by platelets or injured cells. The balance between pro- and anti-apoptotic factors may have relevance for scar development.

\section{Acknowledgments}

This study was supported by the Swedish Research Council, Frimurare Foundation, Jerrings Foundation and Samariten Foundation. We thank Prof. Gerald DiBona, for scrutinizing the manuscript.

\section{References}

1 Schilling JD, Mulvey MA, Hultgren SJ: Structure and function of Escherichia coli type 1 pili: New insight into the pathogenesis of urinary tract infections. J Infect Dis 2001;183(suppl 1):S36-40.

2 Westerlund B, Van Die I, Hoekstra W, Virkola R, Korhonen TK: P fimbriae of uropathogenic Escherichia coli as multifunctional adherence organelles. Zentralbl Bakteriol 1993;278:229_ 237.

3 Mulvey MA, Lopez-Boado YS, Wilson CL, Roth R, Parks WC, Heuser J, Hultgren SJ: Induction and evasion of host defenses by type 1-piliated uropathogenic Escherichia coli. Science 1998;282:1494-1497.

4 Mobley HL, Green DM, Trifillis AL, Johnson DE, Chippendale GR, Lockatell CV, Jones BD, Warren JW: Pyelonephritogenic Escherichia coli and killing of cultured human renal proximal tubular epithelial cells: Role of hemolysin in some strains. Infect Immun 1990;58:12811289.

5 Karpman D, Hakansson A, Perez MT, Isaksson C, Carlemalm E, Caprioli A, Svanborg C: Apoptosis of renal cortical cells in the hemolytic-uremic syndrome: In vivo and in vitro studies. Infect Immun 1998;66:636-644.
6 Uhlen P, Laestadius A, Jahnukainen T, Soderblom T, Backhed F, Celsi G, Brismar H, Normark S, Aperia A, Richter-Dahlfors A: Alphahaemolysin of uropathogenic $E$. coli induces $\mathrm{Ca}^{2+}$ oscillations in renal epithelial cells. Nature 2000;405:694-697.

7 Lieberthal W, Levine JS: Mechanisms of apoptosis and its potential role in renal tubular epithelial cell injury. Am J Physiol 1996;271: F477-F488.

8 Weinrauch Y, Zychlinsky A: The induction of apoptosis by bacterial pathogens. Annu Rev Microbiol 1999;53:155-187.

9 Yang B, El Nahas AM, Thomas GL, Haylor JL, Watson PF, Wagner B, Johnson TS: Caspase-3 and apoptosis in experimental chronic renal scarring. Kidney Int 2001;60:1765-1776.

10 McCarthy NJ, Whyte MK, Gilbert CS, Evan GI: Inhibition of Ced-3/ICE-related proteases does not prevent cell death induced by oncogenes, DNA damage, or the Bcl-2 homologue Bak. J Cell Biol 1997;136:215-227.
11 Petit F, Arnoult D, Lelievre JD, Parseval LM, Hance AJ, Schneider P, Corbeil J, Ameisen JC, Estaquier J: Productive HIV-1 infection of primary CD4+ $\mathrm{T}$ cells induces mitochondrial membrane permeabilization leading to a caspase-independent cell death. J Biol Chem 2002;277:1477-1487.

12 Wang X, Martindale JL, Holbrook NJ: Requirement for ERK activation in cisplatininduced apoptosis. J Biol Chem 2000;275: 39435-39443.

13 Linford NJ, Yang Y, Cook DG, Dorsa DM: Neuronal apoptosis resulting from high doses of the isoflavone genistein: Role for calcium and p42/44 mitogen-activated protein kinase. J Pharmacol Exp Ther 2001;299:67-75.

14 Holmstrom T, Eriksson J: Phosphorylationbased signaling in Fas receptor-mediated apoptosis. Crit Rev Immunol 2000;20:121-152.

15 Goillot E, Raingeaud J, Ranger A, Tepper RI, Davis RJ, Harlow E, Sanchez I: Mitogen-activated protein kinase-mediated Fas apoptotic signaling pathway. PNAS 1997;94:3302-3307.

16 Raff MC: Social controls on cell survival and cell death. Nature 1992;356:397-400. 
17 Richard Dixon, B. NJ: Albumin stimulated p44/p42 extracellular-signal-regulated mitogen-activated protein kinase in opossum kidney proximal tubular cells. Clin Sci 2000;98: 295-301.

18 Koh JS, Lieberthal W, Heydrick S, Levine JS Lysophosphatidic acid is a major serum noncytokine survival factor for murine macrophages which acts via the phosphatidylinositol 3-kinase signaling pathway. J Clin Invest 1998;102: 716-727.

19 Levine JS, Koh JS, Triaca V, Lieberthal W: Lysophosphatidic acid: A novel growth and survival factor for renal proximal tubular cells. Am J Physiol 1997;273:F575-585.

20 Mattsby-Baltzer I, Hanson LA, Kaijser B, Larsson P, Olling S, Svanborg-Eden C: Experimental Escherichia coli ascending pyelonephritis in rats: Changes in bacterial properties and the immune response to surface antigens. Infect Immun 1982;35:639-646.

21 Bachmann BJ: Pedigrees of some mutant strains of Escherichia coli K-12. Bacteriol Rev 1972;36:525-557.

22 Dare E, Li W, Zhivotovsky B, Yuan X, Ceccatelli S: Methylmercury and $\mathrm{H}(2) \mathrm{O}(2)$ provoke lysosomal damage in human astrocytoma D384 cells followed by apoptosis. Free Rad Biol Med 2001;30:1347-1356.

23 Bao W, Thullberg M, Zhang H, Onischenko A, Stromblad S: Cell attachment to the extracellular matrix induces proteasomal degradation of p21CIP1 via Cdc42/Rac1 signaling. Mol Cell Biol 2002;22:4587-4597.

24 Ching JC, Jones NL, Ceponis PJ, Karmali MA Sherman PM: Escherichia coli shiga-like toxins induce apoptosis and cleavage of poly(ADPribose) polymerase via in vitro activation of caspases. Infect Immun 2002;70:4669-4677.

25 Suyama E, Kawasaki H, Taira K: Identification of a caspase 3-independent role of proapoptotic factor Bak in TNF-alpha-induced apoptosis. FEBS Lett 2002;528:63.

26 Zoellner H, Hofler M, Beckmann R, Hufnagl P, Vanyek E, Bielek E, Wojta J, Fabry A, Lockie $\mathrm{S}$, Binder BR: Serum albumin is a specific inhibitor of apoptosis in human endothelial cells. J Cell Sci 1996;109:2571-2580.

27 Fang X, Yu S, LaPushin R, Lu Y, Furui T, Penn LZ, Stokoe D, Erickson JR, Bast RC Jr, Mills GB: Lysophosphatidic acid prevents apoptosis in fibroblasts via G(i)-protein-mediated activation of mitogen-activated protein kinase. Biochem J 2000;352:135-143.
28 Weiner JA, Chun J: Schwann cell survival mediated by the signaling phospholipid lysophosphatidic acid. Proc Natl Acad Sci USA 1999; 96:5233-5238

29 Ireton K, Payrastre B, Chap H, Ogawa W, Sakaue H, Kasuga M, Cossart P: A role for phosphoinositide 3-kinase in bacterial invasion. Science 1996;274:780-782.

30 Guignot J, Breard J, Bernet-Camard MF, Peiffer I, Nowicki BJ, Servin AL, Blanc-Potard AB: Pyelonephritogenic diffusely adhering Escherichia coli EC7372 harboring Dr-II adhesin carries classical uropathogenic virulence genes and promotes cell lysis and apoptosis in polarized epithelial caco-2/TC7 cells. Infect Immun 2000;68:7018-7027

31 Tran SEF, Holmstrom TH, Ahonen M, Kahari V-M, Eriksson JE: MAPK/ERK overrides the apoptotic signaling from Fas, TNF, and TRAIL receptors. J Biol Chem 2001;276: 16484-16490.

32 Wang X, Martindale JL, Liu Y, Holbrook NJ: The cellular response to oxidative stress: Influences of mitogen-activated protein kinase signalling pathways on cell survival. Biochem $\mathrm{J}$ 1998;333:291-300.

33 Xia Z, Dickens M, Raingeaud J, Davis RJ, Greenberg ME: Opposing effects of ERK and JNK-p38 MAP kinases on apoptosis. Science 1995;270:1326-1331.

34 Bild AH, Mendoza FJ, Gibson EM, Huang M, Villanueva J, Garrington TP, Jove R, Johnson GL, Gibson SB: MEKK1-induced apoptosis requires TRAIL death receptor activation and is inhibited by AKT/PKB through inhibition of MEKK1 cleavage. Oncogene 2002;21:6649_ 6656.

35 Kamakura S, Moriguchi T, Nishida E: Activation of the protein kinase ERK5/BMK1 by receptor tyrosine kinases: Identification and characterization of a signaling pathway to the nucleus. J Biol Chem 1999;274:26563-26571.

36 Mody N, Leitch J, Armstrong C, Dixon J, Cohen P: Effects of MAP kinase cascade inhibitors on the MKK5/ERK5 pathway. FEBS Lett 2001;502:21-24.

37 Kiyokawa N, Taguchi T, Mori T, Uchida H, Sato N, Takeda T, Fujimoto J: Induction of apoptosis in normal human renal tubular epithelial cells by Escherichia coli Shiga toxins 1 and 2. J Infect Dis 1998;178:178-184.
38 Cohen GM: Caspases: The executioners of apoptosis. Biochem J 1997;326:1-16.

39 Green D, Kroemer G: The central executioners of apoptosis: Caspases or mitochondria? Trends Cell Biol 1998;8:267-271.

40 Adachi H, Adams A, Hughes FM, Zhang J, Cidlowski JA, Jetten AM: Induction of apoptosis by the novel retinoid AHPN in human Tcell lymphoma cells involves caspase-dependent and independent pathways. Cell Death Differ 1998;5:973-983.

41 Deiss LP, Galinka H, Berissi H, Cohen O, Kimchi A: Cathepsin D protease mediates programmed cell death induced by interferongamma, Fas/APO-1 and TNF-alpha. EMBO J 1996;15:3861-3870.

42 Joza N, Susin SA, Daugas E, Stanford WL, Cho SK, Li CY, Sasaki T, Elia AJ, Cheng HY, Ravagnan L, Ferri KF, Zamzami N, Wakeham A, Hakem R, Yoshida H, Kong YY, Mak TW, Zuniga-Pflucker JC, Kroemer G, Penninger JM: Essential role of the mitochondrial apoptosis-inducing factor in programmed cell death. Nature 2001;410:549-554.

43 Susin SA, Lorenzo HK, Zamzami N, Marzo I, Snow BE, Brothers GM, Mangion J, Jacotot E, Costantini P, Loeffler M, Larochette N, Goodlett DR, Aebersold R, Siderovski DP, Penninger JM, Kroemer G: Molecular characterization of mitochondrial apoptosis-inducing factor. Nature 1999;397:441-446.

44 Iglesias J, Abernethy VE, Wang Z, Lieberthal W, Koh JS, Levine JS: Albumin is a major serum survival factor for renal tubular cells and macrophages through scavenging of ROS. Am J Physiol 1999;277:F711-F722.

45 Tigyi G, Miledi R: Lysophosphatidates bound to serum albumin activate membrane currents in Xenopus oocytes and neurite retraction in PC12 pheochromocytoma cells. J Biol Chem 1992;267:21360-21367.

46 Kumagai N, Inoue CN, Kondo Y, Iinuma K: Mitogenic action of lysophosphatidic acid in proximal tubular epithelial cells obtained from voided human urine. Clin Sci (Colch) 2000;99: 561-567.

47 Eichholtz T, Jalink K, Fahrenfort I, Moolenaar WH: The bioactive phospholipid lysophosphatidic acid is released from activated platelets. Biochem J 1993;291:677-680.

48 Toback FG: Regeneration after acute tubular necrosis. Kidney Int 1992;41:226-246. 